췌장암 수술 후 보조요법으로서 항암화학요법과 항암방사선병용요법의 비교 : 단일기관 후향적 연구

부산대학교 의학전문대학원 내과학교실

김도영 · 최영진 · 설영미 · 김효정

\title{
Adjuvant Chemotherapy Versus Chemoradiation for Patients with Resected Pancreatic Adenocarcinoma: A Single-Center Retrospective Study
}

\author{
Do Young Kim, Young Jin Choi, Young Mi Seol, Hyojeong Kim \\ Department of Hematology-Oncology, Biomedical Research Institute, Pusan National University Hospital, Pusan National University School of \\ Medicine, Busan, Korea
}

Background/Aims: This study aimed to compare the outcomes of patients who received systemic chemotherapy or chemoradiotherapy as adjuvant therapies following pancreatic adenocarcinoma resection.

Methods: We reviewed the medical records of 40 patients with locoregional pancreatic adenocarcinoma who underwent tumor resection at Pusan National University Hospital between 2008 and 2012.

Results: Twenty-nine patients were treated with adjuvant therapy comprising either systemic chemotherapy or chemoradiotherapy after curative-intent surgery. Adjuvant therapy $(p=0.025)$ and complete resection $(p=0.043)$ were associated with longer overall survival. There was no significant difference between chemotherapy and chemoradiotherapy in terms of extending overall survival; however, patients who received chemotherapy had significantly higher survival rates than those who received no adjuvant therapy at all ( $p=0.012$ ).

Conclusions: Adjuvant therapies improve the prognoses of patients with resected pancreatic adenocarcinoma; moreover, chemotherapy produced more favorable outcomes than chemoradiotherapy.

Korean J Pancreas Biliary Tract 2018;23(3):108-115

Keywords: Pancreatic cancer, Chemotherapy, Chemoradiotherapy, Adjuvant $\begin{array}{lr}\text { Received } & \text { Apr. 2,2018 } \\ \text { Revised } & \text { Jul. 3, 2018 } \\ \text { Accepted } & \text { Jul. 3, 2018 }\end{array}$

Corresponding author : Hyojeong Kim

Department of Hematology-Oncology, Biomedical Research Institute, Pusan National University Hospital, Pusan National University School of Medicine, 179 Gudeok-ro, Seo-gu, Busan 49241, Korea

Tel. +82-51-240-7532 Fax. +82-51-256-8330

E-mail; leonkim80@naver.com

This is an Open Access article distributed under the terms of the Creative Commons Attribution Non-Commercial License (http:// creativecommons.org/licenses/by-nc/3.0/) which permits unrestricted non-commercial use, distribution, and reproduction in any medium, provided the original work is properly cited.

Copyright $\odot 2018$ by The Korean Journal of Pancreas and Biliary Tract

\section{INTRODUCTION}

The 5-year relative survival rate of patients with cancer, adjusted for normal life expectancy, has increased by approximately 70\% in Korea between 2010 and 2014, has also increased in the United States between 2005 and 2011. However, the 5-year relative survival rate of patients with pancreatic cancer in the United States was only $8 \%$ in the United States in 2006-2012 and 10.1\% in Korea in 2010$2014 .^{1,2}$ 
Cancer-specific survival rates in patients with pancreatic cancer, which is the fifth leading cause of cancer-related death in Korea, have been slow to improve. Limitations in early detection and the lack of effective therapeutic options substantially contribute to poor prognosis. ${ }^{3}$ However, most patients who were diagnosed early and underwent complete resection still died of the disease. Therefore, it is important to improve post-resection survival as well as early detection.

Based on the results of numerous trials, several pancreatic cancer guidelines recommend adjuvant therapy for all patients with resected pancreatic cancer. ${ }^{4-9}$ However, there is no definite standard regarding the optimal timing and duration of adjuvant therapy. There is also no established standard on the use of chemotherapy alone vs chemoradiotherapy. While some experts suggest that concurrent chemoradiotherapy would be superior to chemotherapy, the survival benefits provided by chemoradiotherapy have not been conclusively shown. The ongoing RTOG 0848 trial, which is investigating the benefits of chemoradiotherapy when administered in sequence with systemic chemotherapy will likely provide critical data in this regard. In this context, our study aimed to compare the effectiveness of systemic chemotherapy versus chemoradiotherapy in the adjuvant setting.

\section{METHODS}

\section{Patients}

We reviewed the medical records of 40 patients with pancreatic adenocarcinoma who underwent curative-intent resection at Pusan National University Hospital between November 2008 and December 2012. The tumor-nodemetastasis classification was used to stage the disease at the time of diagnosis. ${ }^{10}$ Resectability was determined based on the involvement of adjacent structures and the presence of distant metastasis. The requirement for informed consent was waived owing to the study's retrospective nature.

Patients underwent a pylorus-preserving pancreaticoduodenectomy (Whipple procedure) or distal pancreatectomy depending on the tumor's location in the pancreas. Cases with microscopic evidence of tumor extension to within 1 $\mathrm{mm}$ of the surface margin of the resected specimen were classified as having a positive resection margin. ${ }^{11}$ After recovery from surgery, patients underwent chemotherapy, chemoradiotherapy, or supportive care without cancer treatment. Patients receiving adjuvant chemotherapy were treated with one of the following: a 3-week interval of gemcitabine monotherapy $\left(1,000 \mathrm{mg} / \mathrm{m}^{2}\right.$, days 1 and 8$)$, 4-week interval of 5-fluorouracil (5-FU) (425 mg/m², days 1-5) with leucovorin (20 mg/m², days 1-5), or 4-week interval of gemcitabine $\left(1,000 \mathrm{mg} / \mathrm{m}^{2}\right.$, days 1,8 , and 15$)$ with capecitabine (830 mg/m² twice a day, days 1-21). Chemoradiotherapy comprised one of the following therapies: a 4-week interval of 5-FU (15 mg/kg, days 1-4) with cisplatin $\left(60 \mathrm{mg} / \mathrm{m}^{2}\right.$, day 1), 2-week interval of 5-FU (500 mg/m², days 1-3) with leucovorin $\left(20 \mathrm{mg} / \mathrm{m}^{2}\right.$, days $\left.1-3\right)$, or gemcitabine monotherapy (40 mg/m $\mathrm{m}^{2}$ twice weekly). For the therapeutic dose, 40 Gy of radiation was delivered by tomography. After completion of adjuvant therapy, abdominal computed tomography and serum CA 19-9 test were performed every 3 months. Data on tumor characteristics, complete resection, adjuvant therapy, and outcome of treatment were extracted from medical records and analyzed.

\section{Statistical analysis}

The Kaplan-Meier method was used to estimate diseasefree survival (DFS) and overall survival (OS); the log-rank test was used to compare DFS and OS among different groups. DFS was defined as the interval between surgery and detection of disease recurrence, while OS was defined as the interval between surgery and death of any cause. Patients who were alive at the time of the final follow-up visit (May 2017) or those lost to follow-up were censored. A multivariate Cox proportional hazards regression model was used to evaluate the correlations between adjuvant therapy and survival. $p$-values of $<0.05$ were considered statistically significant. The SPSS statistical software (version 18.0; SPSS Inc., Chicago, IL, USA) was used for all analyses. 


\section{RESULTS}

\section{Patient characteristics}

Twenty-seven men (67.5\%) and 13 women (32.5\%) underwent curative-intent surgery. The median age at diagnosis was 63 years (range, 36-76 years), and all patients were histologically diagnosed with pancreatic adenocarcinoma. Most patients ( $\mathrm{n}=39,97.5 \%)$ had T3 disease, while 26 (65.0\%) had lymph node metastasis. Pathological reviews of the resected pancreatic masses revealed that 14 patients (35.0\%) had a positive resection margin. Twenty-nine patients $(72.5 \%)$ received adjuvant therapy with chemotherapy

Table 1. Characteristics of patients

\begin{tabular}{|c|c|c|c|c|}
\hline Characteristics & Total & Adjuvant therapy & $\begin{array}{c}\text { No adjuvant } \\
\text { therapy }\end{array}$ & $p$-value \\
\hline Total patients & 40 & $29(72.5)$ & $11(27.5)$ & \\
\hline Age (median, years) & $63(36-76)$ & $62(36-72)$ & $73(47-76)$ & \\
\hline$<65$ & $24(60.0)$ & $20(50.0)$ & $4(10.0)$ & $0.08^{*}$ \\
\hline$\geq 65$ & $16(40.0)$ & $9(22.5)$ & $7(17.5)$ & \\
\hline \multicolumn{5}{|l|}{ Sex } \\
\hline Male & $27(67.5)$ & $20(50.0)$ & $7(17.5)$ & $1.0^{*}$ \\
\hline Female & $13(32.5)$ & $9(22.5)$ & $4(10.0)$ & \\
\hline \multicolumn{5}{|l|}{ Pathologic T stage } \\
\hline $\mathrm{T} 1$ & $1(2.5)$ & $1(2.5)$ & 0 & $1.0^{*}$ \\
\hline T3 & $39(97.5)$ & $28(70.0)$ & $11(27.5)$ & \\
\hline \multicolumn{5}{|l|}{ Pathologic N stage } \\
\hline NO & $14(35.0)$ & $11(27.5)$ & $3(7.5)$ & $0.715^{*}$ \\
\hline $\mathrm{N} 1$ & $26(65.0)$ & $18(45.0)$ & $8(20.0)$ & \\
\hline \multicolumn{5}{|l|}{ Resection margin involved } \\
\hline No (R0 resection) & $24(60.0)$ & $18(45.0)$ & $6(15.0)$ & $0.457^{*}$ \\
\hline Yes & $14(35.0)$ & $9(22.5)$ & $5(12.5)$ & \\
\hline (R1 resection) & $10(25.0)$ & $7(17.5)$ & $3(7.5)$ & \\
\hline (R2 resection) & $4(10.0)$ & $2(5.0)$ & $2(5.0)$ & \\
\hline Unknown & $2(5.0)$ & $2(5.0)$ & 0 & \\
\hline \multicolumn{5}{|l|}{ Adjuvant therapy } \\
\hline Chemotherapy & & $13(44.8)$ & - & \\
\hline 5-fluorouracil with leucovorin & & $7(24.1)$ & & \\
\hline Gemcitabine monotherapy & & $4(13.8)$ & & \\
\hline Gemcitabine with capecitabine & & $2(6.9)$ & & \\
\hline Chemoradiotherapy & & $16(55.2)$ & - & \\
\hline 5-fluorouracil with cisplatin & & $8(27.6)$ & & \\
\hline 5-fluorouracil with leucovorin & & $4(13.8)$ & & \\
\hline Gemcitabine monotherapy & & $4(13.8)$ & & \\
\hline \multicolumn{5}{|l|}{ Relapse } \\
\hline No & $8(20.0)$ & $6(15.0)$ & $2(5.0)$ & \\
\hline Yes & $32(80.0)$ & $23(57.5)$ & $9(22.5)$ & \\
\hline Palliative therapy after relapse & $24(75.0)$ & $19(59.4)$ & $5(15.6)$ & \\
\hline \multicolumn{5}{|l|}{ Death } \\
\hline No & $3(7.5)$ & $3(7.5)$ & 0 & \\
\hline Yes & $37(92.5)$ & $26(65.0)$ & $11(27.5)$ & \\
\hline DFS (median, months) & 9.3 & 10 & 1.2 & $0.201^{\dagger}$ \\
\hline OS (median, months) & 24.2 & 25.1 & 10.3 & $0.018^{\dagger}$ \\
\hline
\end{tabular}

Values are presented as number (\%)

T, tumor; N, node; DFS, disease-free survival; OS, overall survival.

" $p$-values were derived from Fisher's exact test.

${ }^{\dagger} p$-values were derived from Kaplan-Meier analyses and log-rank tests. 
$(n=13,32.5 \%$ of all patients) or chemoradiotherapy $(n=16$, $40.0 \%$ of all patients). Thirty-two patients (80.0\%) relapsed, 24 of whom received palliative therapy. Thirty-seven patients $(92.5 \%)$ had died by May 2017 (Table 1).

\section{Survival analysis}

The median DFS of all patients was 9.3 months (95\% confidence interval $[\mathrm{CI}], 5.8-12.8$ months), while the median OS was 24.2 months (95\% CI, 21.4-27.1 months). The adjuvant therapy group showed better OS (25.1 vs. 10.3 months, $p=0.018$ ) than non-adjuvant therapy group; however, there was no significant difference in DFS (10.0 vs. 1.2 months, $p=0.201)$. With respect to the treatment method, the systemic chemotherapy group showed a higher survival rate than the non-adjuvant therapy group (median OS, 28.2 vs. 10.3 months, $p=0.012$ ). However, the chemoradiotherapy group did not show a significant improvement in OS over the non-adjuvant therapy group (median OS, 24.2 vs. 10.3 months, $p=0.115$ ) (Fig. 1).

\section{Predictive factors for treatment}

On univariate analysis, older age ( $\geq 65$ years) at diagnosis, lymph node metastasis, complete resection, and adjuvant therapy were not significantly correlated with DFS. Moreover, DFS was not significantly different between the chemotherapy vs. chemoradiotherapy groups. However, receipt of adjuvant therapy $(p=0.025)$ and complete resection $(p=0.043)$ were significantly associated with improved OS.
On multivariate logistic regression, undergoing adjuvant therapy (hazard ratio [HR], 0.42 [95\% CI, 0.2-0.9], $p=0.025$ ) was the only factor predictive of improved OS (Table 2, Fig. 2).

\section{Adjuvant treatment method}

On subgroup analysis of the 29 patients who underwent adjuvant therapy, neither systemic chemotherapy nor chemoradiotherapy had a survival advantage relative to the other (DFS, 10.1 vs. 8.7 months, respectively, $p=0.73$; OS,

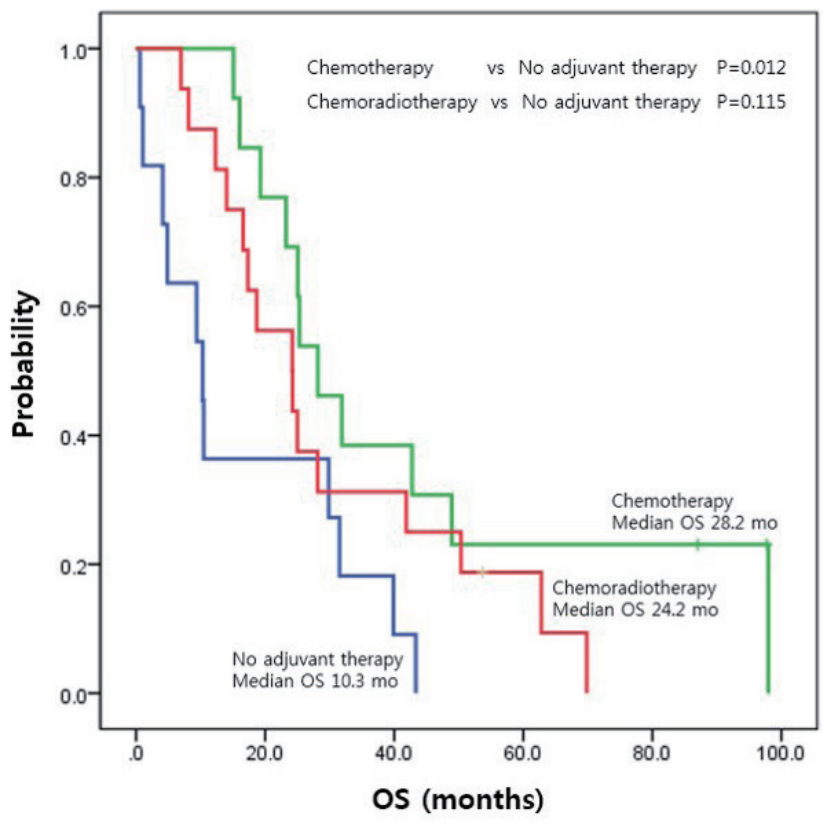

Fig. 1. Kaplan-Meier curves showing the overall survival of patients with resected pancreatic cancer according to the adjuvant therapy modalities administered. OS, overall survival; mo, months.

Table 2. Univariate and multivariate analyses of factors affecting the overall survival of all patients

\begin{tabular}{|c|c|c|c|c|}
\hline \multirow{2}{*}{ Variable } & \multicolumn{2}{|c|}{ Univariate } & \multicolumn{2}{|c|}{ Multivariate } \\
\hline & $\mathrm{HR}(95 \% \mathrm{Cl})$ & $p$-value* & HR (95\% CI) & $p$-value* \\
\hline Adjuvant therapy & $0.42(0.20-0.88)$ & 0.025 & $0.42(0.20-0.90)$ & 0.025 \\
\hline Lymph node involvement & $1.12(0.56-2.23)$ & 0.746 & NA & \\
\hline Age ( $\geq 65$ years) & $1.07(0.54-2.11)$ & 0.839 & NA & \\
\hline Resection margin involved & $0.48(0.24-0.98)$ & 0.043 & $0.51(0.25-1.04)$ & 0.064 \\
\hline Progression & $2.19(0.84-5.72)$ & 0.11 & NA & \\
\hline Palliative therapy after relapse & $1.24(0.62-2.49)$ & 0.525 & NA & \\
\hline
\end{tabular}

$\mathrm{HR}$, hazard ratio; $\mathrm{Cl}$, confidence interval; NA, not applicable.

${ }^{*} p$-values were derived via Cox regression analysis. 
28.2 vs. 24.2 months, respectively, $p=0.188$ ). Older age ( $\geq 65$ years) at diagnosis, lymph node metastasis, and complete resection did not significantly influence DFS and OS (Table 3).

\section{Adverse events}

Adverse events during treatment were reported in 18 of 29 patients $(62.1 \%)$ who underwent adjuvant therapy. The common adverse events were neutropenia, thrombocytope-

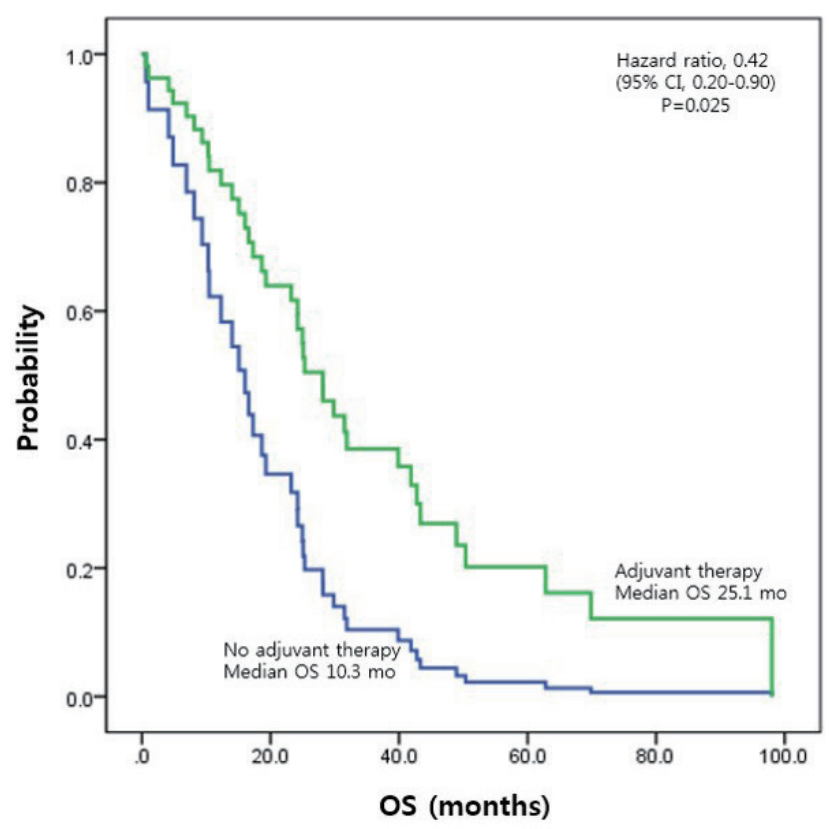

Fig. 2. Kaplan-Meier curves showing the overall survival of patients with resected pancreatic cancer according to whether they received adjuvant therapy. $\mathrm{Cl}$, confidence interval; OS, overall survival; mo, months. nia, anorexia, and asthenia. Grade 3/4 adverse events were more frequently reported in the chemoradiotherapy group than in the chemotherapy group; however, this difference was not significant (Table 4). Patients who experienced these toxicities were treated via conservative methods.

\section{DISCUSSION}

Currently, surgical resection offers the only chance for cure in patients with nonmetastatic pancreatic cancer. Only $10-20 \%$ of patients have potentially resectable disease at diagnosis; ${ }^{12}$ however, $60-80 \%$ of patients experience recurrence despite curative surgery for pancreatic adenocarcinoma and die of metastatic disease. ${ }^{13,14}$ For this reason, adjuvant treatment after successful tumor resection has been studied (Table 5). Oettle et al. and Neoptolemos et al. reported that adjuvant chemotherapy significantly prolonged DFS by approximately 6 months in patients with resected pancreatic cancer (CONKO-001, ESPAC-1, and ESPAC-3 trials). ${ }^{8,9,12,15}$ Furthermore, Kalser and Ellenberg ${ }^{13}$ and Klinkenbijl et al. ${ }^{14}$ reported that combining radiation and chemotherapy was effective (GITSG and EORTC40891 trials). Based on these results, adjuvant therapy is now recommended by several guidelines. ${ }^{4-6}$

In our study, the adjuvant therapy produced better outcomes than surgery-alone. Regarding nodal status, which is one of the most important prognostic factors after complete

Table 3. Univariate and multivariate analyses of factors affecting the overall survival of patients who underwent adjuvant treatment

\begin{tabular}{|c|c|c|c|c|}
\hline \multirow{2}{*}{ Variable } & \multicolumn{2}{|c|}{ Univariate } & \multicolumn{2}{|c|}{ Multivariate } \\
\hline & HR $(95 \% \mathrm{Cl})$ & $p$-value* & HR $(95 \% \mathrm{Cl})$ & $p$-value* \\
\hline Chemotherapy & $0.59(0.26-1.31)$ & 0.193 & NA & NA \\
\hline Chemoradiotherapy & $1.71(0.76-3.83)$ & 0.193 & NA & NA \\
\hline Lymph node involvement & $1.14(0.50-2.58)$ & 0.756 & NA & NA \\
\hline Age ( $\geq 65$ years) & $0.92(0.38-2.23)$ & 0.858 & NA & NA \\
\hline Resection margin involved & $0.49(0.20-1.16)$ & 0.102 & NA & NA \\
\hline Progression & $2.55(0.75-8.65)$ & 0.107 & NA & NA \\
\hline Palliative therapy after relapse & $1.69(0.68-4.16)$ & 0.254 & NA & NA \\
\hline
\end{tabular}

HHR, hazard ratio; $\mathrm{Cl}$, confidence interval; NA, not applicable.

${ }^{*} p$-values were derived via Cox regression analysis. Since none of the factors were significantly associated with overall survival $(p<0.05)$ on univariate analysis, multivariate analysis was not applicable. 
Table 4. Toxicities associated with treatment

\begin{tabular}{|c|c|c|c|c|c|}
\hline \multirow{2}{*}{ Variable } & \multicolumn{2}{|c|}{ Chemotherapy $(n=13)$} & \multicolumn{2}{|c|}{ Chemoradiotherapy $(n=16)$} & \multirow{2}{*}{$p$-value* } \\
\hline & Grade $1 / 2$ & Grade 3/4 & Grade $1 / 2$ & Grade 3/4 & \\
\hline \multicolumn{6}{|l|}{ Hematologic toxicity } \\
\hline Neutropenia & $2(15.4)$ & $1(7.7)$ & $4(30.8)$ & $4(30.8)$ & 0.14 \\
\hline Anemia & $2(15.4)$ & 0 & 3 & 0 & 0.81 \\
\hline Thrombocytopenia & $1(7.7)$ & 0 & $4(30.8)$ & $1(7.7)$ & 0.12 \\
\hline \multicolumn{6}{|c|}{ Nonhematologic toxicity } \\
\hline Anorexia & $2(15.4)$ & 0 & $3(23.1)$ & 0 & 0.81 \\
\hline Nausea & $1(7.7)$ & 0 & $1(7.7)$ & $1(7.7)$ & 0.67 \\
\hline Vomiting & 0 & 0 & $1(7.7)$ & 0 & 0.36 \\
\hline Asthenia & $1(7.7)$ & $1(7.7)$ & $3(23.1)$ & $2(15.4)$ & 0.32 \\
\hline Dyspnea & 0 & 0 & $1(7.7)$ & 0 & 0.67 \\
\hline Neuropathy & $1(7.7)$ & 0 & 0 & 0 & 0.26 \\
\hline
\end{tabular}

${ }^{*} p$-values were derived using Fisher's exact test and the chi-square test.

Table 5. Trials of adjuvant therapy for resected pancreatic cancer

\begin{tabular}{|c|c|c|c|c|c|}
\hline Trial & Arms & No. of patients & Local recurrence & Median survival (months) & $p$-value* \\
\hline \multirow[t]{2}{*}{ ESPAC- $3^{7}$} & $5-\mathrm{FU}$ & 551 & $\mathrm{NR}$ & 23 & 0.39 \\
\hline & Gem & 537 & NR & 24 & \\
\hline \multirow[t]{4}{*}{$\mathrm{ESPAC}-1^{8}$} & 5-FU/LV & 142 & & 20 & 0.011 \\
\hline & No chemo & 147 & & 16 & \\
\hline & 5-FU/LV CCRT & 145 & & 14 & 0.05 \\
\hline & No RT & 144 & & 17 & \\
\hline \multirow[t]{2}{*}{ CONKO-001 } & Gem & 186 & $34 \%$ & 23 & 0.01 \\
\hline & Obs & 182 & $41 \%$ & 20 & \\
\hline \multirow[t]{2}{*}{$\mathrm{EORTC}^{14}$} & 5-FU CCRT & 104 & $15 \%$ & 25 & 0.208 \\
\hline & Obs & 103 & $15 \%$ & 19 & \\
\hline \multirow[t]{2}{*}{ GITSC $^{15}$} & 5-FU CCRT & 21 & NR & 20 & 0.03 \\
\hline & Obs & 22 & NR & 11 & \\
\hline
\end{tabular}

${ }^{*} p$-values were derived using Fisher's exact test and the chi-square test.

pancreatic cancer resection, the 5-year survival rate after pancreaticoduodenectomy is only $10 \%$ for patients with node-positive disease and 30\% for those with node-negative disease. ${ }^{16}$ When our data were analyzed using a multivariate Cox regression model applying known prognostic factors including nodal status, more favorable outcomes were observed in patients who received adjuvant therapy as well.

Comparisons of the effectiveness of chemotherapy vs. chemoradiotherapy have yielded conflicting results, and no standard has been established as to which regimen should be used. Likewise, our data also did not produce any definitive conclusions; however, patients who received chemotherapy showed a significantly prolonged OS over those who did not receive any adjuvant therapy, while those who received chemoradiotherapy did not. Similar results were obtained in other large-scale studies. ${ }^{8,15}$ Therefore, chemotherapy may be preferable over chemoradiotherapy as an adjuvant treatment. To explain the differences in OS in the 
absence of significant differences in DFS, further studies of factors such as regimen-associated toxicity and effect of palliative therapy after relapse are required.

Gemcitabine or 5-FU is often used when administering chemoradiotherapy; the recent RTOG 9704 trial showed no significant difference between the 2 agents. ${ }^{17}$ According to several studies and a meta-analysis published in 2013, 5-FU and gemcitabine are considered the most effective adjuvant chemotherapy regimens for patients with resected pancreatic cancer. ${ }^{18,19}$ Results from the recent ESPAC-4 trial indicated that adding capecitabine to gemcitabine was better than gemcitabine alone. ${ }^{20}$

Recently, Hsieh et al. ${ }^{21}$ reported a cohort study performed with propensity score matching in Taiwan in which 588 patients were divided into 3 groups: adjuvant chemoradiotherapy, sequential chemotherapy-radiotherapy, and chemotherapy. Their study showed that adjuvant chemoradiotherapy (HR, 0.398) and sequential chemotherapy-radiotherapy (HR, 0.307) showed improved survival over adjuvant chemotherapy alone. All treatment regimens included intensitymodulated radiotherapy, which they claimed contributed to minimizing toxicities from administering combination radiotherapy and chemotherapy and to improving survival. However, it is also a retrospective study and has limitations for a conclusion. A large-scale prospective study of this method is currently underway and we need to wait for the result.

Our study had several limitations. First, owing to its small number of patients, retrospective nature, and single-center setting, the results carried insufficient statistical power. Second, the patients' performance statuses, tumor locations, and surgical methods were not considered; furthermore, the patients did not receive homogeneous chemotherapy and chemoradiotherapy regimens.

In conclusion, we found that adjuvant therapies had a positive effect on the prognosis of patients with resected pancreatic adenocarcinoma and that adjuvant chemotherapy produced more favorable OS outcomes than chemoradiotherapy, although this advantage was not observed in terms of DFS. Since the patient characteristics and toxicities in the chemotherapy and chemoradiotherapy groups were similar, the difference in OS may be attributable to differing patients conditions after relapse.

\section{요 약}

본 연구는 췌장암 환자가수술 후 보조요법으로서 항암화학요법 또는 항암-방사선병용요법을 시행받는 경우에 있어서 치료 성적의 차이가 있는지 조사하기 위해 시행하였다. 2008년에서 2012년까지 부산대학교병원에서 수술을 시행한 40 명의 췌장 선암 환자들의 의무기록을 조사하였다. 근치적 목적으로 수술을 받은 환자 중 29명이 항암화학 요법 또는 항암-방사 선병용요법의 보조요법을 시행받았다. 보조요법의 시행 $(p=0.025)$ 과 완전 절제 $(p=0.043)$ 가 더 긴 전체 생존기간과 연관이 있었다. 보조요법으로서 항암화학요법을 시행한 군과 항암-방사선병용요법을 시행한 군에서 전체 생존 기간은 유의하게 다르지 않았으나 보조요법을 하지 않은 군과 비교하였을 때에는 보조요법으로 항암화학요법을 시행한 군에서 유의하게 높은 전체 생존율을 보였다. 수술 후 보조요법은 췌장 선암 환자의 예후를 향상시키며, 항암화학요법이 항암-방사선 병용요법보다 양호한 결과를 보인다.

국문 색인: 췌장암, 보조 항암요법, 보조 항암방사선병용요법

\section{Conflicts of Interest}

The authors have no conflicts to disclose.

\section{Acknowledgments}

This work was supported by a clinical research grant from Pusan National University Hospital in 2017.

\section{REFERENCES}

1. Siegel RL, Miller KD, Jemal A. Cancer statistics, 2017. CA Cancer J Clin 2017:67:7-30.

2. Jung KW, Won YJ, Oh CM, et al. Cancer statistics in Korea: incidence, mortality, survival, and prevalence in 2014. Cancer Res Treat 2017:49:292-305.

3. Halbrook CJ, Lyssiotis CA. Employing metabolism to improve the diagnosis and treatment of pancreatic cancer. Cancer Cell 2017;31:5-19. 
4. Seufferlein T, Bachet JB, Van Cutsem E, Rougier P. Pancreatic adenocarcinoma: ESMO-ESDO Clinical Practice Guidelines for diagnosis, treatment and follow-up. Ann Oncol 2012;23 Suppl 7:vii33-vii40.

5. Khorana AA, Mangu PB, Berlin J, et al. Potentially curable pancreatic cancer: American Society of Clinical Oncology Clinical Practice Guideline. J Clin Oncol 2016;34:2541-2556.

6. Khorana AA, Mangu PB, Berlin J, et al. Potentially curable pancreatic cancer: American Society of Clinical Oncology Clinical Practice Guideline Update. J Clin Oncol 2017;35:2324-2328.

7. Neoptolemos JP, Stocken DD, Bassi C, et al. Adjuvant chemotherapy with fluorouracil plus folinic acid vs gemcitabine following pancreatic cancer resection: a randomized controlled trial. JAMA 2010;304:10731081.

8. Neoptolemos JP, Stocken DD, Friess $H$, et al. A randomized trial of chemoradiotherapy and chemotherapy after resection of pancreatic cancer. N Engl J Med 2004;350:1200-1210.

9. Oettle $H$, Post $S$, Neuhaus $P$, et al. Adjuvant chemotherapy with gemcitabine vs observation in patients undergoing curative-intent resection of pancreatic cancer: a randomized controlled trial. JAMA 2007;297:267-277.

10. Wittekind C, Asamura H, Sobin LH. TNM atlas, 6th edition. Chichester, Wiley Blackwell, 2014.

11. Kim KS, Kwon J, Kim K, Chie EK. Impact of resection margin distance on survival of pancreatic cancer: a systematic review and metaanalysis. Cancer Res Treat 2017;49:824-833.

12. Oettle $H$, Neuhaus $P$, Hochhaus A, et al. Adjuvant chemotherapy with gemcitabine and long-term outcomes among patients with resected pancreatic cancer: the CONKO-001 randomized trial. JAMA 2013;310:1473-1481.

13. Kalser MH, Ellenberg SS. Pancreatic cancer. Adjuvant combined radiation and chemotherapy following curative resection. Arch Surg 1985;120:899-903.
14. Klinkenbij JH, Jeekel J, Sahmoud T, et al. Adjuvant radiotherapy and 5 -fluorouracil after curative resection of cancer of the pancreas and periampullary region: phase III trial of the EORTC gastrointestinal tract cancer cooperative group. Ann Surg 1999;230:776-782; discussion 782-784.

15. Neoptolemos JP, Dunn JA, Stocken DD, et al. Adjuvant chemoradiotherapy and chemotherapy in resectable pancreatic cancer: a randomised controlled trial. Lancet 2001;358:1576-1585.

16. Kang MJ, Jang JY, Chang YR, Kwon W, Jung W, Kim SW. Revisiting the concept of lymph node metastases of pancreatic head cancer: number of metastatic lymph nodes and lymph node ratio according to N stage. Ann Surg Oncol 2014;21:1545-1551.

17. Regine WF, Winter KA, Abrams R, et al. Fluorouracil-based chemoradiation with either gemcitabine or fluorouracil chemotherapy after resection of pancreatic adenocarcinoma: 5-year analysis of the U.S. Intergroup/RTOG 9704 phase III trial. Ann Surg Oncol 2011;18:13191326.

18. Liao WC, Chien KL, Lin YL, et al. Adjuvant treatments for resected pancreatic adenocarcinoma: a systematic review and network metaanalysis. Lancet Oncol 2013;14:1095-1103.

19. Yu Z, Zhong W, Tan ZM, Wang LY, Yuan YH. Gemcitabine adjuvant therapy for resected pancreatic cancer: a meta-analysis. Am J Clin Oncol 2015:38:322-325.

20. Neoptolemos JP, Palmer DH, Ghaneh P, et al. Comparison of adjuvant gemcitabine and capecitabine with gemcitabine monotherapy in patients with resected pancreatic cancer (ESPAC-4): a multicentre, openlabel, randomised, phase 3 trial. Lancet 2017;389:1011-1024.

21. Hsieh MC, Chang WW, Yu HH, et al. Adjuvant radiotherapy and chemotherapy improve survival in patients with pancreatic adenocarcinoma receiving surgery: adjuvant chemotherapy alone is insufficient in the era of intensity modulation radiation therapy. Cancer Med 2018;7:2328-2338. 